\title{
Indian scientists speak out against bomb
}

[NEW DELHI] Euphoria in India about last week's nuclear tests is gradually giving way to unrest and disappointment in parts of the scientific community as plans are developed for a movement to temper New Delhi's further nuclear initiatives.

D. P. Dasgupta, professor emeritus in the electrical engineering department of the Indian Institute of Science in Bangalore, says he is "sticking my neck out" to get such a movement started. He is receiving support from physicist Sanjay Biswas and other faculty members at the institute and, he hopes, elsewhere.

A nationwide signature campaign protesting against India's development of nuclear weapons has been launched in preparation for a conference of what Dasgupta describes as "right-thinking scientists" on 30 May in Bangalore.

"Right now we are in a desperate minority," he says, aware that widespread support for the tests means that their wider implications may take time to sink in. But he is confident that the movement will grow.

Dasgupta says he has been flooded with calls from scientists from all over the country offering support after he and other speakers protesting against the tests were attacked by supporters of the nuclear bomb at a meeting in Bangalore last week.

"Some of us feel strongly about the nuclear 'weaponization' which we can ill afford when our priorities should be elsewhere," says Dasgupta.

"What is there to gloat about imitating a 50 -year-old nuclear weapons technology when 50 per cent of our people are illiterate and require food, water and hospitals?" $\mathrm{He}$ says he was "much prouder when we developed a supercomputer on our own which the United States did not want to sell to us".

Meanwhile, 75 scientists from institutions run by the Department of Atomic Energy (DAE) have condemned the tests. Expressing "dismay and unhappiness at the action of the government", they say in a joint statement that the scientific achievement in conducting the tests has been exaggerated, and complain that India "has been committed to an expensive weapons programme without a national debate".

"The tests are bound to vitiate the atmosphere in the south Asian regions, triggering a nuclear weapons race, exacerbating the tensions that already exist, and making even more difficult the achievement of peaceful coexistence and cooperation amongst the nations of this region," the statement says.

"We don't see what immediate threats to national security forced this move, particularly when people's needs in terms of educa-

\section{Despair over pay sparks Russian strike}

[MOscow] About 2,000 scientists went on strike in Vladivostok last week because of the government's non-payment of wages. The strike, by members of the Far Eastern branch of the Russian Academy of Sciences (RAS), formed part of a nationwide series of demonstrations.

The scientists, who blocked several major roads in the region, were also making political demands. They called for a change to the Russian president and cabinet, on the grounds that they had shown themselves to be unable to support Russian science.

"Our strike is an act of despair," said Georgyi Elyakov, a vice-president of the RAS and president of its local branch. "We have no other way to draw attention to the problems of science in the region. Previously this was one of the best scientifically productive parts of the country, with its own scientific fleet, perfectly equipped laboratories and wellfinanced expeditions. Now all this is gone."

The day after the strike, more than 100,000 people — including 12,000 in Moscow alone - took part in protests against education reforms proposed by the government. As well as proposing to reduce the number of lecturers by 20 per cent and the number of students by 15 per cent, the new minister of education, Alexander Tikhonov, has drawn up a plan to give stateowned universities greater autonomy.

Meeting representatives of the academics' and scientists' trade union, Oleg Sysoev, the vice prime minister, argued that that the reforms "will draw resources from financial and other structures to the education system; at the same time the state will control the situation".

But the Russian Union of University Rectors says that it does not believe in the state's ability "to control the situation" while it is unable to support the universities financially. In 1997, education received only 2 per cent of the total state budget, and it is unlikely that this will increase in 1998.

"The other reason for our protest is the debt of 10 billion new roubles (US\$1.6 billion) that the state owes to education workers," said Nina Merkulova, an official of the central committee of the academics' and scientists' trade union. "We have not received our salaries for many months."

Russia's prime minister, Sergei Kirienko, has decided to defer a discussion of the reforms that was to have taken place at a cabinet meeting next month. Carl Levitin

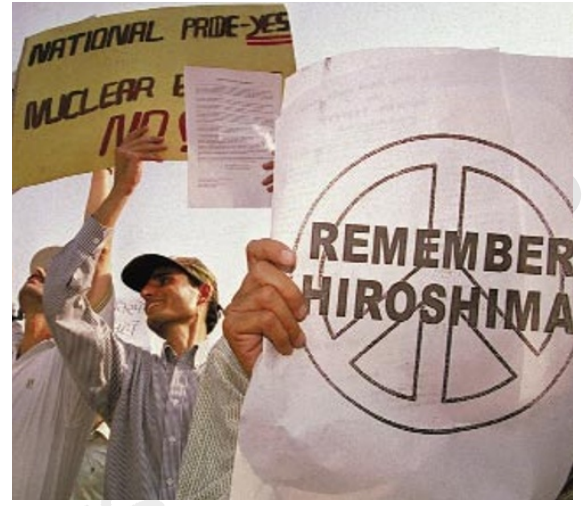

Lessons of history: activists protest in New Deli against five nuclear tests.

tion, health, infrastructure and industrial development are urgent."

The authors of the statement come from the Institute of Mathematical science (Chennai, formerly Madras), Mehta Research Institute (Allahabad), Tata Institute of Fundamental Research (Mumbai, formerly Bombay), Institute of Physics (Bhubaneswar), Indira Gandhi Centre for Atomic Research in Kalpakkam — all of which are funded by the DAE — as well as from the Aeronautical Development Agency under the Defence Research Development Organization.

Other signatories are from the Indian Institute of Science, the five Indian Institutes of Technology, the S. N. Bose National Centre for Basic Sciences in Calcutta, the Centre for Theoretical Studies in Bangalore, and universities. Some expatriate Indian scientists in Germany, Brazil, Taiwan and Sweden also signed.

"No technocrat will oppose the Pokran [tests]," says Nataraja Sarma, a retired nuclear physicist from the DAE. "But the protests will increase when sanctions start to bite."

The political implications of the tests appear to have caused some rethinking among science policy-makers. M. G. K. Menon, a physicist and member of the ruling Bharatiya Janata Party, warned last week that the country will pay a heavy price if it decides to downgrade other sciences and give importance only to "strategic" science.

P. R. Chari, co-director of the Institute of Peace and Conflict Studies in New Delhi, expresses concern that the nuclear debate in India is dominated by "hawks", and that liberal voices are muted because dissent is considered unpatriotic.

"Indian nationalism has become inextricably linked with nuclear options and people who oppose them are considered traitors," says Kanti Bajpai, professor of international relations at the Jawaharlal Nehru University in New Delhi.

K.S.Jayaraman 